\title{
Peluang dan Tantangan Penerapan Prinsip Permanent Soverignity Over Natural Resources di Indonesia
}

\author{
Popi Tuhulele \\ Program Doktor Ilmu Hukum Universitas Hasanuddin, Makassar, Indonesia \\ E-mail: popi.awal@gmail.com
}

\begin{abstract}
Principle of permanent sovereignty over natural resources (PSNR) in international law are regulated in UN General Assembly Resolution Number 1515 (XV) 15 December 1960, and Resolution Number 1803, 14 December 1962, which recognizes permanent sovereignty over natural resources. The fact is that Indonesia which is rich in natural resources is not fully sovereign of its natural resources. This is influenced by limited capital ownership and also limited human resources. Because permanent sovereignty over natural resources should be directly proportional to the welfare of the people of Indonesia. This paper uses normative research methods with a database in the form of library data, online surveys, and several related legal materials, then described descriptively, and interpreted comprehensively. In this context, the importance of management and management of natural resources by the state. Because it is closely related to the risks posed by the exploitation and exploration of natural resources on geological and political aspects. For this reason, it is very important for Indonesia to adopt principles in supporting the rule of law at regional, international and national levels and protect the sovereignty and interests of the country.
\end{abstract}

Keywords: Sovereignty; Natural Resources.

\section{A. PENDAHULUAN}

Negara sebagai subyek hukum utama dan terpenting dibanding dengan subjeksubjek hukum internasional lainnya. Telah diatur diatur hak dan kewajiban sebagai negara dalam Konvensi Montevideo 1933. Konvensi Montevideo 1933 mengenai hak dan kewajiban negara dalam Pasal 1 menyebutkan bahwa negara sebagai subjek dalam hukum internasional harus memiliki empat unsur yaitu : penduduk yang tetap, wilayah tertentu, pemerintahan yang berdaulat dan kapasitas untuk berhubungan dengan Negara lain, ${ }^{1}$ dalam perkembangannya unsur konstitutif negara dalam kapasitasnya melakukan hubungan dengan negara lain tergeser dengan kedaulatan sebagai unsur konstitutif,

1 Thontowi, Jawahari dan Iskandar, Pranoto. (2006), Hukum Internasional Kontemporer, Bandung: Refika Aditama, h. 105. 
mengingat artinya yang sangat penting dalam lingkup hubungan internasional yang lebih luas. $^{2}$

Kedaulatan merupakan manifestasi kekuasaan tertinggi yang dimilik negara untuk secara bebas melakukan berbagai aktifitas dalam yurisdiksinya sesuai kepentingannya asalkan kegiatan tersebut tidak bertentangan dengan hukum internasional. ${ }^{3}$ Kedaulatan suatu negara dalam perkembanganya tidak lagi bersifat absolut, akan tetapi pada batasbatas tertentu negara harus menghormati kedaulatan negara lain, terutama kegiatan yang melintasi batas negaranyta, yang diatur dalam hukum internasional.

Menurut Jean Charpentier sebagaimana yang dikutip oleh Beor Mauna menyatakan bahwa kedaulatan mempunyai pengertian positif dan negatif. Dalam pengertian positif kedaulatan negara adalah untuk mengeksplorasi sumber daya alam di dalam wilayah negaranya demi kesejahteraan rakyatnya. Hal inilah yang disebut dengan kedulatan permanen atas sumber daya alam ${ }^{4}$

Kedaulatan dalam konteks hukum internasional terbagi atas, kedaulatan internal (internal sovereignty) dan kedaulatan eksternal (external sovereignty) dan kedaulatan teritorial. ${ }^{5}$ Kedaulatan eksternal yang merupakan objek kajian hukum internasional, terkait dengan hubungan antara suatu negara dengan negara lainnya, sedangkan kedaulatan internal adalah kedaulatan dalam hubungannya dengan kekuasaan tertinggi yang dipegang dalam suatu negara dan bagaiman negara di dalam penyelegaraanya dan kedaulatan teritorial adalah kedaulatan penuh dan eksklusif atas individu dan bendabenda yang terdapat dalam wilayah negara.

Yang dimaksud dengan kedaulatan atas wilayah adalah kewenangan yang dimiliki suatu negara untuk melaksanakan kewenangannya sebatas dalam wilayah-wilayah yang telah menjadi bagian dari kekuasaannya. Kedaulatan merupakan salah satu prinsip dasar bagi terciptanya hubungan internasional yang damai. ${ }^{6}$ Kedaulatan negara juga merupakan prinsip yang esensial dalam pengaturan sumber daya alam, dalam sejarah peradaban manusia dan negara-negara moderen, selalu muncul konflik yang sebahagian nbesar disebabkan oleh permasalahan penguasaan atas suatu wilayah. Konflik ini muncul dikaren akan perebutan atas sumber daya alam di wilayah tersebut.

Konflik mengenai sumber daya alam mustahil untuk diabaikan dalam dunia kita. Sejarah telah membuktikan, kebutuhan terhadap sumber daya alam telah mendorong kolonialisasi Eropa terhadap penjuru dunia, lalu menetapkan batas-batas teritorial negarabangsa koloninya. faktor utama berbagai perang sipil yang meluluhlantakan komunitas Afrika adalah perang untuk memenangkan kontrol distribusi minyak, berlian dan emas. Kenyataannya, bahwa sumber daya alam adalah problematika bagi keberadaan manusia dan negara, ${ }^{7}$ tidak terkecuali dengan Indonesia, negara yang kaya sumber daya lama.

Sejumlah instrumen internasional menetapkan dengan jelas dan tegas bahwa sumber daya alam yang berada dalam wilayah suatu negara, maka sumber daya tersebut berada dibawah penguasaan negara tersebut. Didalam kovenan tentang sosial dan politik

2 Mauna, Boer. (2000). Hukum Internasional Pengertian, Peranan dan Fungsi Dalam Era Dinamika Global, Bandung: Alumni, h. 24.

3 Librayanto, Romi. (2010). Ilmu Negara: Suatu Pengantar, Makassar: Pustaka Refleksi, h. 158.

4 Mauna, Boer. Op Cit. h. 25.

5 C, Anwar. (2011), Teori dan Hukum Konstitusi, Malang: Intrans Publishing, h. 3.

6 Thontowi, Jawahari dan Iskandar, Pranoto. Op Cit,. h. 169.

7 Amstrong, Chris Keadilan Atas Sumbert Daya Alam Dalam Perspektif Teori Egalitarian Global, Southamton University, Oxford University Pres, h. 3. 
1966 secara khusus, menyatakan bahwa semua bangsa, untuk tujuan-tujuan mereka sendiri, dapat mengelola kekayaan alam mereka dan sumberdayanya. ${ }^{8}$

Hak penguasaan negara dengan sebesar-besar kemakmuran rakyat akan diwujudkan dengan kewajiban negara sebagai berikut:

1) Pemanfaatan (bumi dan air) serta hasil yang didapat (kekayaan alam), dengan segala bentuknya, haruslah secara nyata meningkatkan kemakmuran dan kesejahteraan rakyat.

2) Melindungi dan menjamin segala hak-hak rakyat yang terdapat didalam atau diatas bumi, air dan berbagai kekayaan alam tertentu yang dapat dihasilkan secara langsung atau dinikmati langsung oleh rakyat.

3) Mencegah segala tindakan dari pihak manapun yang akan menyebabkan rakyat tidak mempunyai kesempatan atau akan kehilangan haknya dalam menikmati kekayaan alam. ${ }^{9}$

Upaya melindungi sumber daya alam bertujuan memberikan kemakmuran bagi negara dan rakyat adalah mutlak. Faktanya tidak ada negara tanpa sumber daya alam betapapun miskinnya negara itu dalam ukuran-ukuran makroekonomi. Argumennya, penguasaan terhadap satuan wilayah geografis tertentu merupakan bagian integral dari pendefinisian konsep negara. Tanpa penguasaan ruang geografis berikut sumber daya alam, suatu negara dalam kompetisi geopolitik di tataran internasional diyakini akan menjadi sangat lemah dan ruang kehidupannya terancam. ${ }^{10}$

Bagi negara hak prerogative kedaulatan negara selalu berakar pada hak penentuan nasib sendiri dengan tujuan utama pembangunan ekonomi untuk negara berkembang, prinsip permanent sovereignty over natural resources (PSNR) merupakan mutlak hak prerogatif negara, alam Resolusi Majelis Umum Perserikatan Bangsa-Bangsa (PBB) Nomor 1515 (XV) 15 Desember 1960, ${ }^{11}$ Majelis Umum PBB merekomendasikan hak kcdaulatan setiap negara untuk mengatur kekayaan dan sumber daya alamnya harus dihormati dan selanjutnya Resolusi Nomor 1803, 14 Desember 1962, yang mengakui adanya kedaulatan permanen negara atas sumber daya alam (permanent sovereignty over natural resources).

Prinsip kedaulatan negara telah ditegaskan dalam bebarapa keputusan arbitrase internasional. Salah satunya keputusan Parkerings v. Lithuania tahun 2007, yang menegaskan, kewenangan negara untuk mengatur dan merupakan hak dan privilege yang tidak dapat disangkal (undeniable rights and privilege). Namun demikian, penerapan prinsip kedaulatan negara tidaklah serta-merta memberikan kewenangan mutlak bagi negara untuk bertindak sewenang-wenang. ${ }^{12}$

8 Amstrong, Chris. (2014). Melawan Kedaulatan Permanen Atas Sumber Daya, Southamton University, h. 2.

9 Laporan Tim Analisa dan Evaluasi Hukum Hak Penguasaan Negara Terhadap Sumber Daya Alam (UU NO. 22 Tahun 2001 Tentang Minyak Dan Gas Bumi), Badan Pembina Hukum Nasional Depertemen Hukum Dan HAM Tahun 2008

10 Makmur Keliat, Kedaulatan Permanen Atas Sumber Daya Alam, Kompas 22 November 2012

11 Resolusi Majelis Umum PBB Nomor 1803 (XVII) tanggal 14 Desember 1962, antara lain berbunyi: "The right of peoples and nations to permanent sovereignty over their natural wealth and resources must be exercised in the interest of their national development and of the well-being of the people of the Stated concerned; The exploration, development and dispotion of such resources, as well as the import of the foreign capital required for these purpose, should be in conformity with the rules and conditions which the peoples and nations freely consider to be necessary or desirable with regard to the authorization, restriction, or prohibition of such activities;"

12 Taufik, Giri Ahmad. Freeport dan Posisi Hukum Indonesia, Kompas 20 Maret 2017 
Prinsip tersebut memerlukan pembatasan guna memberikan kepastian dan jaminan bagi investor guna memproyeksi keuntungan yang diharapkan dari investasinya di masa depan. Posisi hukum Internasional dalam hal ini adalah untuk menyeimbangkan antara jaminan atas keuntungan yang diharapkan (legitimate and reasonable expectations) dan hak dari negara dalam mengatur untuk kepentingan masyarakat. ${ }^{13}$

Disisi lain tidak banyak perbincangan muncul di tataran internasional setelah sekitar lima dasawarsa gagasan kedaulatan permanen atas SDA dikeluarkan, Norma internasional yang dicoba dibangun lewat gagasan ini bahkan seakan meredup dan senyap di tengah gegap gempita konsep kedaulatan individual. Ia juga kian terlupakan ketika wacana dominan yang muncul sejak awal 2000-an terfokus pada isu tentang tanggung jawab negara untuk melindungi. Dua isu ini, secara tak langsung atau sengaja, telah meminggirkan arti penting penguatan kedaulatan negara dan lebih banyak energi diplomatik diarahkan untuk mengurangi kekuasaan negara itu. ${ }^{14}$

Fakta yang ada tetap menunjukkan semangat negara terhadap penguasaan sumber daya alam terus meningkat. Terlihat dari menurunnya penguasaan perusahan minyak internasional dan posisinya diganti oleh perusahan minyak nasional. Untuk itu tulisan ini mengkaji penerapan prinsip Permanent Soverignity Over Natural Resources di Indonesia.

\section{B. METODE PENELITIAN}

Penulisan ini mengunakan jenis penelitian normatif yang mengkaji peluang dan tantangan Penerapan prinsip permanent overignity over natural resources di Indonesia. Serta manfaat penguasaan atas sumber daya alam oleh negara terhadap perbaikan kesejahteraan rakyat Indonesia, dalam tulisan ini basis data yang digunakan adalah berupa data pustaka, survei online, dan beberapa bahan hukum terkait dengan tema tulisan ini. Hasil pengumpulan data tersebut selanjutnya uraikan secara deskrptif, dan dinterpertasikan guna mendapatkan gambaran yang konprehensif mengenai tema permasalahan.

\section{PEMBAHASAN}

Di era globalisasi, konflik yang terjadi dalam hubungan internasional pada umumnya di picu oleh semakin langkanya sumber daya alam, egosentrisme masingmasing entitas dalam melakukan interaksi satu sama lain. ${ }^{15}$ Di sisi lain negara yang memiliki kekayaan sumber daya alam sering kali tidak memiliki kedaulatan atas sumber daya alamnya karena berbagai faktor, seperti kelangkaan sumberdaya maupun modal dalam mengeksplorasi dan mengeksplotasi sumber daya alam yang dimilikiya. Untuk itu negara membutuhkan modal untuk membiayai pembangunannya, apabila pendanaan dalam negeri tidak mencukupi maka, salah satu cara untuk mendapatkan suntikan modal, dengan menarik investasi asing.

Pada dasarnya, negara-negara sedang berkembang sangat membutuhkan investasi asing. Tujuan investasi adalah mempercepat laju pembangunan di negara tersebut. Pada umumnya yang memiliki modal atau investasi adalah negara-negara maju.

13 Ibid

14 Makmur Keliat, Op Cit

15 Hata. (2012), Hukum Internasional sejarah dan perkembangan Hingga Pasca Perang Dingin, Malang: Setara Perss, h. 57.

92 | S A S I Vol. $26 \mathrm{No.1}$, Januari- Maret 2020 
Bangsa Indonesia sebagai pemilik atas kekayaan alam, selanjutnya memberikan kekuasan kepada "Negara" untuk mengatur dan memanfaatkan kekayaan nasional tersebut sebaik-baiknya agar tercapai keadilan dazn kemakmuran dalam masyarakat. Pengertian dikuasai negara, adalah bahwa negara menguasai seluruh sumber daya alam, untuk kepentingan rakyat serta kemakmuran rakyat. ${ }^{16}$

Sebagaimana diketahui konstitusi Indonesia menjamin hak permanen negara atas sumber daya alam, dalam Pasal 33 UUD 1945, yang menyatakan bahwa bumi dan air dan kekayaan alam yang terkandung didalamnya dikuasai oleh negara dan dipergunakan untuk sebesar-besarnya kemakmuran rakyat.

Pada masa transisi lahirnya serangkaian perundang-undangan di bidang sumberdaya alam yang nilai-nilai dasar pengaturannya tidak dapat dilepaskan dari konteks paradigma perekonomian global. Bagi perekonomian Indonesia masuknya modal asing merupakan tuntutan keadaan baik dalam bidang ekonomi maupun politik Indonesia. Alternatif lain dengan penghimpunan dana pembangunan melalui investasi modal secara langsung sangat baik dibandingkan dengan dana internasional lainnya seperti pinjaman dari luar negeri. ${ }^{17} \mathrm{Hal}$ ini selain dapat menghasilkan devisa secara langsung bagi negara, kegiatan penanaman modal secara langsung tentunya dapat menghasilkan manfaat yang sangat signifikan bagi negara, karena tujuan penanaman modal (host country) karena sifatnya yang permanen/jangka panjang. ${ }^{18}$ Kedaulatan negara merupakan prinsip yang esensial dalam pengaturan sumber daya alam. Prinsip kedaulatan negara menjadi dasar bagi negara memiliki otoritas dan kedaulatan di seluruh wilayah teritorial.

Faham kedaulatan Indonesia baik aspek intern dan ekstern tercantum dalam Proklamasi Kemerdekaan. Kedaulatan negara mengenai kemerdekaan pemerintahan, kemerdekaan daerah, kemerdekaan rakyat, yang ketiga-tiganya berisi penuh dan sempurna, mengandung maksud kepada pengertian negara sebagai kesatuan territorial yang berdaulat dalam batas-batas wilayahnya terhadap penduduknya melalui suatu mekanisme penyelenggaraan pemerintahan yang bebas. ${ }^{19}$

The United Nation Declaration on Permanent Sovereignty over National Resources merupakan instrumen internasional yang berhasil dibentuk oleh negara-negara untuk kemudian berlaku sebagai hukum dan pedoman dimana sebagian isinya menyinggung masalah pengaturan dan perlindungan bagi kegiatan ataupun aset investasi asing di negara penerima.

Ada beberapa butir penting dari resolusi ini yang menarik untuk dicatat. Pertama, kedaulatan permanen negara terhadap sumber daya alam dilaksanakan demi kesejahteraan penghuninya dan pembangunan nasional. Kedua, eksplorasi dan pengembangan sumber daya alam harus sesuai aturan-aturan yang ada di masyarakatnya. Ketiga, dalam pengelolaan sumber daya alam dan pembagiam keuntungan dalam kerjasama antara negara dan investor tidak boleh berdampak pada pelemahan terhadap konsep kedaulatan permanen negara atas sumber daya alam. Keempat, dengan alasan kepentingan publik dan keamanam tidakan tindakan nasionalisasi dan penyitaan

${ }^{16}$ Laporan Tim Analis dan Evaluasi Hukum Hak Penguasaan Negara Terhadap Sumber Daya Alam (UU NO. 22 Tahun 2001 Tentang Minyak Dan Gas Bumi), Op Cit

17 Ahmad, Yulianto. (2003), Peran Multilateral Investment Guarantee Agency (MIGA) dalam Kegiatan Investasi, Jurnal Hukum Bisnis Volume 22 Nomor 5, h 39.

18 Nasution, Asmin. (2008), Transparansi dalam Penanaman Modal, Medan: Pustaka Bangsa Press, h. 1 .

19 Ardhiwisastra, Yudha Bhakti. (1999), Imunitas Kedaulatan Negara di Forum Pengadilan Asing, Bandung: Alimni, h. 59.

93 | S A S I Vo1. 26 No.1, Januari-Maret 2020 
diizinkan. Kelima, kontroversi yang muncul sebagai akibat dari tindakan nasionalisasi dan penyitaan itu dapat diselesaikan melalui arbitrase atau ajudikasi internasional. ${ }^{20}$

Dukungan PBB sangat penting sehubungan dengan kepemilikan hak sumber daya alam Migas. Resolusi Majelis Umum PBB Nomor 1803 (XVII) tahun 1962 memberikan dampak yang besar bagi negara-negara berkembang untuk menuntut kedaulatan penuh atas sumber daya alam strategis Migas, yaitu: ${ }^{21}$

1) Setiap negara berdaulat atas sumber kekayaan alam;

2) Pembagian keuntungan yang diperoleh dari pengelolaan sumber daya alam tidak boleh merusak kedaulatan suatu negara;

3) Dalam kerja sama internasional untuk pembangunan ekonomi dilaksanakan atas dasar penghormatan terhadap kedaulatan negara atas sumber kekayaan alam yang dimilikinya;

4) Hak dan kedaulatan rakyat dan bangsa atas kekayaan alam yang dimilikinya, harus dilaksanakan semata-mata untuk kepentingan pembangunan nasional dan kesejahteraan rakyat dari negara yang bersangkutan.

Kedaulatan negara terhadap kekayaan alamnya menurut Schrijver, bahwa suatu negara memiliki hak-hak sebagai berikut: ${ }^{22}$

1) Memiliki, menggunakan dan kemerdekaan untuk memanfaatkan kekayaan alamnya;

2) Kebebasan untuk menentukan dan mengawasi potensi, eksplorasi, pembangunan, eksploitasi, pemanfaatan dan pemasaran kekayaan alamnya;

3) Pengelolaan dan konversi sumber kekayaan alam negara sesuai dengan kebijakan pembangunan nsional dan lingkungannya;

4) Pengaturan penanaman modal, termasuk pengaturan terhadap masuknya penanaman modal asing dan kegiatan para investor, termasuk aliran keluar penanaman modalnya; dan

5) Hak untuk menasionalisasi atau ekspropriasi harta milik, baik milik warga negaranya atau warga negara asing (dengan memberikan ganti rugi).

Mempertimbangkan bahwa setiap tindakan dalam hal ini didasarkan pada pengakuan terhadap hak yang dimiliki setiap negara untuk mengatur kckayaan dan sumber daya alam sesuai dengan kepentingan nasional dan atas penghormatan terhadap kemerdekaan ekonomi negara. ${ }^{23}$ Menyatakan bahwa, hak dari negara atas kedaulatan permanen terhadap kekayaan dan sumber daya alam harus dilaksanakan dan bertujuan untuk kepentingan pembangunan nasional kesejahteraan rakyat negara yang bersangkutan, pelaksanaan kedaulatan negara yang bebas dan bermanfaat atas sumber daya alam mereka harus diujudkan dengan saling menghormati di antara negara yang didasarkan pada persamaan kedaulatan. Pelanggaran terhadap hak-hak negara atas kedaulatan pada kekayaan dan sumber daya alam adalah bertentangan asas Piagam PBB dan menghalangi pengembangan kerja sama internasional dan pemeliharaan perdamaian. Persetujuan penanaman modal asing yang dibuat oleh atau di antar negara harus ditaati dengan itikad baik, negara dan organisasi internasional harus sepenuhnya

20 Nasution, Asmin Op Cit

21 Adolf, Huala. (2008), Dasar-Dasar Hukum Kontrak Internasional, Bandung: Refika Aditama, h. 211.

22 Schrijver, Nico dalam Qureshi, Asif. (1999), International Economic Law, London: Sweet and Maxwell, h. 38 dalam Adolf, Huala, Op. Cit., h. 230-231.

23 Elsam, Kedaulatan Permanen atas Sumber Daya Alam Diadopsi oleh Resolusi Majelis Umum 1803 (XVII), 14 Desember 1962, Koleksi Pusat Dokumentasi Elsam 
dan dengan kesadaran menghormati kedaulatan bangsa dan negara atas kekayaan dan sumber daya alam. ${ }^{24}$

Prinsip PSNR berupaya untuk menyeimbangkan kepentingan antara negara tuan rumah dan investor asing dengan memperhatikan hukum dari negara tuan rumah dan perkembangan hukum internasional. Pengaruh Resolusi dari Majelis Umum PBB telah dianggap sebagai bentuk kompromi antara negara-negara berkembang dengan negaranegara maju dan merupakan prinsip hukum yang dapat diterima oleh para pihak.

Kedaulatan permanen negara atas sumber daya alam seperti migas amatlah penting di Indonesia. Sumber daya migas merupakan sumber daya strategis, maka sumber ini ditempatkan secara khusus yang juga memerlukan pengaturan secara khusus. Karena kepemilikan sumber daya migas Migas dalam yurisdiksi suatu negara (baik di darat (onshore) atau di laut (offshore) tunduk pada hukum nasional negara. Termasuk sumber daya alam migas yang berada di wilayah berdaulat negara.

Lebih lanjut Majelis Umum PBB menerbitkan Resolusi Nomor 3201 (S-VI) pada 1 Mei 1974 dan deklarasi tentang pembentukan Tata Ekonomi Internasional Baru dan Program Hak-hak Ekonomi dan Kewajiban Negara (Charter of Economic Rights and Duties of States (CERDS). CERDS memberikan legalitas adanya hak-hak ekonomi dan kewajiban negara dalam mengelola sumber daya ekonomi, termasuk hak melakukan pengambilalihan melalui nasionalisasi maupun ekspropriasi.

Mengacu pada prinsip kedaulatan permanen atas sumber daya alam, landasan kebijakan pengelolaan sumber daya alam indonesia belum secara eksplisit diatur dalam undang-undang. Contohnya prinsip kedaulataan negara belum secara jelas diatur dalam Pasal 2 Undang-undang Migas menyatakan bahwa:

Penyelenggaraan kegiatan usaha Minyak dan Gas Bumi yang diatur dalam Undangundang ini berasaskan ekonomi kerakyatan, keterpaduan, manfaat, keadilan, keseimbangan, pemerataan, kemakmuran bersama dan kesejahteraan banyak, keamanan, keselamatan, dan kepastian hukum serta berwawasan lingkungan.

Selanjutnya ujud kedaulatan negara belum diatur secara tegas pada kekuasaan negara atas pertambangan.Terlihat dalam Pasal 4 Undang-Undang Migas menyatakan: ${ }^{25}$

1) Minyak dan Gas Bumi sebagai sumber daya alam strategis tak terbarukan yang terkandung di dalam wilayah hukum pertambangan Indonesia merupakan kekayaan nasional yang dikuasai oleh negara.

2) Penguasaan oleh negara sebagaimana dimaksud dalam ayat (1) diselenggarakan oleh pemerintah sebagai pemegang kuasa pertambangan.

3) Pemerintah sebagai pemegang kuasa pertambangan membentuk badan pelaksana sebagaimana dimaksud dalam Pasal 1 angka 23.

Pengertian dikuasai oleh negara sebenarnya telah dengan tepat diterjemahkan dan atau diartikan oleh UU Pertambangan Migas, yaitu:

(1) Negara memiliki kuasa pertambangan atas bahan galian;

(2) Kuasa pertambangan meliputi kegiatan-kegiatan: eksplorasi, eksploitasi, pengangkutan, pemurnian/pengolahan, dan distribusi/pemasaran;

24 Ibid

25 LIhat, Undang-Undang Nomor 22 Tahun 2001 Tentang Minyak dan Gas Bumi, (Lembaran Negara Republik Indonesia (LNRI) Tahun 2001 Nomor 136, Tambahan Lembaran Negara (TLN) Nomor 4152

95 | S A S I Vo1.26 No.1, Januari- Maret 2020 
(3) Khusus untuk endapan migas, pelaksanaan pertambangan migas hanya diusahakan oleh negara dan dilakukan oleh perusahaan.

Cerminan prinsip kedaulatan negara dalam UU Migas antara lain tersirat dalam Pasal 6 ayat (2) yang berbunyi sebagai berikut:

1) Kepemilikan sumber daya alam tetap di tangan Pemerintah sampai pada titik penyerahan;

2) Pengendalian manajemen operasi berada pada badan pelaksana;

3) Modal dan risiko seluruhnya ditanggung Badan Usaha atau Bentuk Usaha Tetap.

Mengacu pada prinsip hukum di atas, maka adopsi prinsip PSNR dipandang penting dalam UU Migas. Maknanya, negara menguasai segala sesuatu yang berada di dalam wilayah kedaulatannya. Hal ini dapat dikaitkan dengan Putusan MK Nomor: 36/PUU$\mathrm{X} / 2012$, menyatakan bahwa negara dan hubungannya dengan sumber daya alam migas yang dikonstruksikan dalam bentuk konmtrak atau perjanjian kerjasama antara BP Migas sebagai pihak dari Pemerintah atau yang mewakili Pemerintah dengan Badan Usaha (BU) atau Bentuk Usaha Tetap (BUT) sebagaimana diatur dalam Undang-undang Migas adalah tidak dibolehkan karena bertentangan dengan prinsip penguasaan negara yang dimaksud oleh konstitusi.

Negara dalam hal ini seharusnya dapat melakukan pengelolaan atas sumber daya alam migas secara langsung, sehingga negara mendapat keuntungan yang lebih besar dari pengelolaan sumber daya alam, dengan pengelolaan oleh negara secara langsung dipastikan seluruh hasil keuntungan yang diperoleh akan menjadi keuntungan negara yang secara tidak langsung akan membawa manfaat besar bagi rakyat. Badan usaha atau badan usaha dalam pengelolaan sumber daya alam migas dapat mereduksi makna kedaulatan negara atas sumber daya alam migas yang bertentangan dengan amanat Pasal 33 UUD NRI 1945.

Dalam pengelolaan sumber daya alam migas negara dengan pihak swasta dalam kerjasamanya harus dalam hubungn yang bersifat publik dengan pemberiam konsesi dan perijinan yang sepenuhnya harus di kontrol oleh negara. Jika kontrak dilakukan dengan cara keperdataan dapat mendegradasi kedaulatan negara atas sumber daya alam migas. Pemisahan fungsi kebijakan dan pengaturan dengan lembaga pengelolaan dan bisnis migas secara langsung, mengakibatkan tereduksinya kedaulatan negara atas sumber daya alam migas.

Penguasaan negara terhadap sumber daya alam dan cabang-cabang produksi yang penting bagi negara dan menguasai hajat hidup orang banyak harusnya dimaknai sebagai mandat yang harus dilaksanakan oleh negara untuk membuat kebijakan (beleid), mengadakan pengurusan (bestuursdaad), pengaturan (regelendaad), pengelolaan (beheersdaad), dan pengawasan (toezichthoudensdaad) untuk sebesar-besarnya kemakmuran rakyat.

Seharusnya fungsi dari negara tidak hanya melakukan pengaturan namun juga mengurus dan menyelenggarakan. Dalam melaksanakan hal ini, maka negara yang diwakili oleh aparatur pemerintah memiliki kewenangan bertindak untuk mencampuri kegiatan-kegiatan ekonomi guna melaksanakan tugas-tugas menyelenggarakan kepentingan umum. Secara sederhana dapat dideskripsikan penguasaan dan pengaturan migas harus tetap dikuasai oleh negara dengn cara tertentu untuk digunakan sebesarbesarnya kemakmuran rakyat sesuai dengan semangat dan filosofi bangsa Indonesia.

Sejalan dengan jiwa Pasal 33 UUD NRI Tahun 1945 adalah melindungi kedaulatan sumber daya alam secara geo-hukum, geo-ekonomi, geo-politik dan geososial. 
Penguasaan sumber daya alam migas yaitu, kepemilikan sumber daya alam migas (mineral rights) oleh negara, pemegang kewenangan penyelenggaraan kegiatan usaha (mining rights) oleh pemerintah dan hak pengusahaan kegiatan usaha (economic rights) diberikan kepada perusahaan Migas negara (NOCs).

Begitu pentingnya sumber daya alam migas bagi negara maka penting kiranya penguasaan dan penyelengaraan pengelolaan sumber daya alam ada pada negara.seperti yang dilakukan negara-negara lain, contohnya Norwegia yang memberikan hak kepemilikan dan hak khusus atas pengelolaan sumber daya alam Migas kepada negara untuk kepentingan masyarakat secara keseluruhan. Norwegia melakukan perubahan terhadap tata kelola migas yang semula birokratis menjadi professional dengan membentuk dua BUMN baru, yaitu Petoro AS dan Gassco AS pada 2001. Petoro AS adalah perusahaan yang bertanggung jawab atas investasi negara di lapangan migas Norwegia yang dioperasikan oleh operator asing dalam bentuk $100 \%$ kepemilikan saham dimiliki oleh negara. Sedangkan Gassco AS perusahaan negara yang bertanggung jawab untuk pengangkutan gas alam. Yang $100 \%$ sahamnya dikuasai oleh negara. Gassco adalah perusahaan netral yang dapat digunakan oleh semua kontraktor gas. Norwegia secara tegas membedakan fungsi kebijakan, regulasi dan fungsi bisnis dalam tata kelola Migas.

\section{P E N U T U P}

Kadulatan atas penyelengaraan dan pengelolaan sumber daya alam migas amatlah penting. Karena kegiatan ini memiliki resiko besar berhubungan dengan aspek geologi, komersialitas dan risiko politik. Setiap negara mempunyai strategi masing-masing terkait kedaulatan migas. Partisipasi negara, dalam hal ini pemerintah sangatlah penting untuk melindungi kedaulatan dan kepentingan negara. Adopsi prinsip PSNR dipandang penting dalam mendukung aturan-aturan hukum pada tataran regional, nasional dan internasional.

\section{DAFTAR PUSTAKA}

\section{Buku}

[1] Adolf, Huala. (2008), Dasar-Dasar Hukum Kontrak Internasional, Bandung: Refika Aditama.

[2] Amstrong, Chris Keadilan Atas Sumbert Daya Alam Dalam Perspektif Teori Egalitarian Global, Southamton University, Oxford University Pres.

[3] Amstrong, Chris. (2014). Melawan Kedaulatan Permanen Atas Sumber Daya, Southamton University.

[4] Ardhiwisastra, Yudha Bhakti. (1999), Imunitas Kedaulatan Negara di Forum Pengadilan Asing, Bandung: Alimni.

[5] C, Anwar. (2011), Teori dan Hukum Konstitusi, Malang: Intrans Publishing.

[6] Hata. (2012), Hukum Internasional sejarah dan perkembangan Hingga Pasca Perang Dingin, Malang: Setara Perss.

[7] Librayanto, Romi. (2010). Ilmu Negara: Suatu Pengantar, Makassar: Pustaka Refleksi.

[8] Mauna, Boer. (2000). Hukum Internasional Pengertian, Peranan dan Fungsi Dalam Era Dinamika Global, Bandung: Alumni. 
[9] Nasution, Asmin. (2008), Transparansi dalam Penanaman Modal, Medan: Pustaka Bangsa Press.

[10] Thontowi, Jawahari dan Iskandar, Pranoto. (2006), Hukum Internasional Kontemporer, Bandung: Refika Aditama.

\section{Jurnal dan Lain-Lain}

[11] Ahmad, Yulianto. (2003), Peran Multilateral Investment Guarantee Agency (MIGA) dalam Kegiatan Investasi, Jurnal Hukum Bisnis Volume 22 Nomor 5.

[12] Elsam, Kedaulatan Permanen atas Sumber Daya Alam Diadopsi oleh Resolusi Majelis Umum 1803 (XVII), 14 Desember 1962, Koleksi Pusat Dokumentasi Elsam.

[13] Makmur Keliat, Kedaulatan Permanen Atas Sumber Daya Alam, Kompas 22 November 2012

[14] Taufik, Giri Ahmad. Freeport dan Posisi Hukum Indonesia, Kompas 20 Maret 2017

[15] Laporan Tim Analisa dan Evaluasi Hukum Hak Penguasaan Negara Terhadap Sumber Daya Alam (UU NO. 22 Tahun 2001 Tentang Minyak Dan Gas Bumi), Badan Pembina Hukum Nasional Depertemen Hukum Dan HAM Tahun 2000 